\title{
Desarrollo de un Web-GIS para el patrimonio arquitectónico Mudéjar
}

\author{
Marta Quintilla
}

\section{Resumen}

En este estudio se presenta el desarrollo de un Web-GIS para representar el patrimonio mudéjar en Aragón, un listado de 227 edificios que necesitan ser inventariados para su correcta documentación. Algunos de los bienes son especialmente representativos con elementos arquitectónicos singulares y forman parte del patrimonio mundial. Esta situación precisa un Sistema de Información del Patrimonio Arquitectónico, una base de datos que pueda incorporar información relativa a la identificación y localización, datos históricos, tipo de protección, características geométricas, constructivas, estado de conservación y tipos de intervención; un soporte común que permita contener todos los materiales disponibles de un elemento patrimonial. El diseño y desarrollo de este Web-GIS, se ha enfocado en la protección del patrimonio mudéjar de Aragón y su relación con el entorno y la normativa urbanística y de protección. La información gráfica de esta información y su relación con el patrimonio y su geolocalización, facilitan un soporte para el análisis espacial, para su conservación y divulgación. Supone un instrumento adicional para la toma de decisiones, facilitando la elaboración de inventarios encaminados a la protección y conservación, y contribuye a dotar de una visión del edificio a escala urbana y territorial, no solo como un ente aislado.

\section{Palabras clave}

patrimonio arquitectónico, Web-GIS, estandarización, semántica, planeamiento urbano.

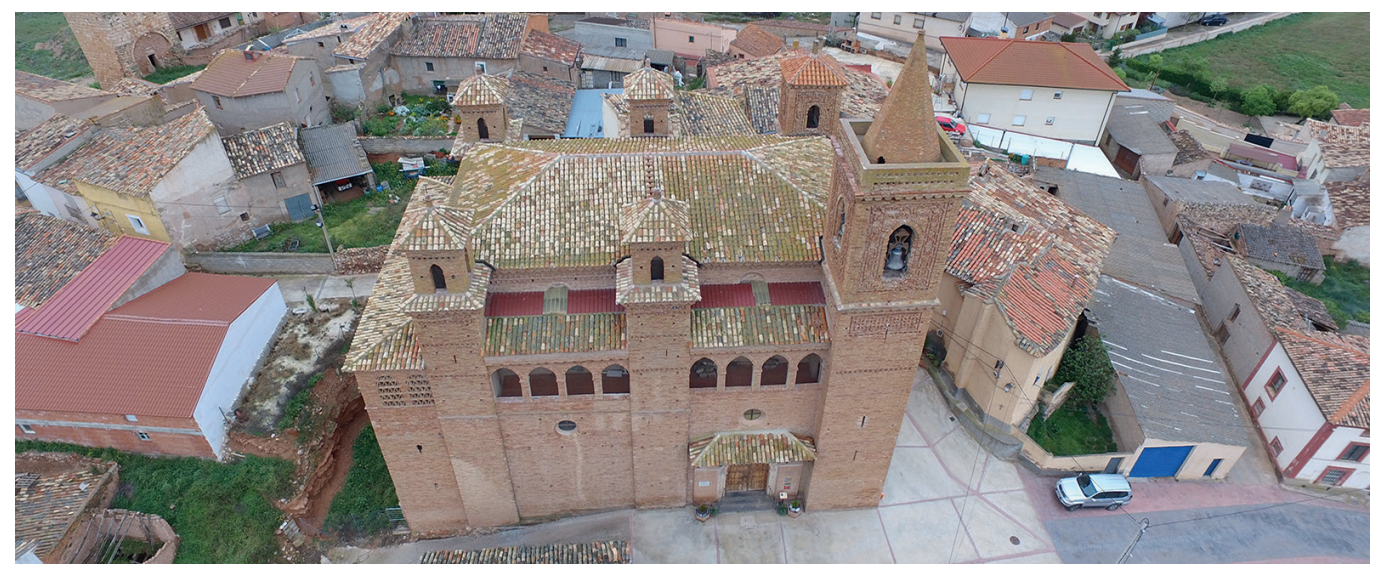




\section{Introducción}

La difusión del patrimonio cultural en las últimas décadas ha ido ligado al desarrollo de las herramientas informáticas utilizadas por los investigadores para la visualización y gestión de la información. A su vez, ha afectado a la forma de trabajar de los investigadores, ya que permite generar mayor documentación con gran precisión y debe ser almacenada y gestionada de un modo rápido, accesible y sencillo.

Desde la Convención de la UNESCO de 1972 [UNESCO 1972], en la que se promovían las necesidades de conservación y protección del Patrimonio, así como "adoptar las medidas jurídicas, científicas, técnicas, administrativas y financieras adecuadas, para identificar, proteger, conservar, revalorizar y rehabilitar ese patrimonio", todas las disciplinas han trabajado conjuntamente para llevar a cabo esta labor.

Los avances en la metodología de trabajo y en el modo de documentación en el ámbito de la visualización digital del Patrimonio, se han regido principalmente, por la Carta de Londres [Denard 2009], sobre la visualización del patrimonio y los Principios de Sevilla [International Forum ofVirtual Archaeology $20 \mathrm{II}$, centrados en la arqueología virtual. En ellas se insta a la transparencia en la representación, diferenciando claramente lo original de lo reconstruido, además de recomendar la adaptación de la visualización a los objetivos de investigación, preservación y divulgación [Statham 2019].

Actualmente, la elaboración de documentación para la conservación, difusión y protección del patrimonio, supone un gran reto para los profesionales. La heterogeneidad de datos, leyes, estándares, tecnologías y audiencias, dificulta la adecuada organización de la información. La elección del Sistema de Gestión por parte de las instituciones, provoca problemas de transferencia, comunicación y dificultad de distribución del conocimiento entre los distintos actores que trabajan en torno al patrimonio, así como con otros inventarios. En general, los problemas son comunes en la mayoría de los países: bajo grado de uso tecnológico, escasa actualización y estandarización. Por ello, asegurar la correcta información a lo largo del tiempo, es una prioridad. La tendencia para el mantenimiento e interoperabilidad entre bases de datos, es establecer un marco normativo común internacional, mediante la utilización de estándares. A nivel de la Unión Europea se está trabajando en numerosos proyectos para la tutela y protección de los bienes culturales como Parthenos, Ariadne, Carare o 3D-Icons entre otros, dictando unos mínimos comunes para la conservación y documentación del patrimonio en todos los países de la Unión. Se están promoviendo iniciativas para homogeneizar y unificar a través de la normalización de la información, mediante la elaboración de guías que recogen las recomendaciones y estándares internacionales para el inventariado y documentación del patrimonio, así como estándares para el intercambio de documentación, metadatos e información geográfica.

\section{Estandarización e interoperabilidad}

Para permitir la máxima interoperabilidad y accesibilidad, la utilización de software y lenguaje de código abierto, garantiza el intercambio correcto de información y asegura su permanencia y mantenimiento a lo largo del tiempo a pesar de los continuos avances tecnológicos, favoreciendo que las instituciones puedan mantener sus sistemas de gestión del patrimonio. El desarrollo de estándares para intercambio de información lo está llevando a cabo el W3C (World Wide Web Consortium), mediante la creación de estándares como XML (eXtensible Markup Language) que provee herramientas para el intercambio de información y metadatos entre aplicaciones. El lenguaje XML también se utiliza para la estructura semántica de la información, pero no considera la dimensión espacial de ellos. Para ello, el OGC (Open Geospatial Consortium) ha puesto sus esfuerzos en definir estándares que permitan la interoperabilidad de este tipo de datos a través de la web, desarrollando entre otros, el estándar GML (Geographic Markup Language), muy similar al XML, pero enfocado a mostrar objetos geográficos [Cerutti et al. 20 I 5]. Este lenguaje es usado por directivas internacionales como INSPIRE (Infrastructure for Spatial Information in Europe) para promover el desarro- 
llo de infraestructuras de datos espaciales y el intercambio estandarizado de información. En el caso de la visualización de datos 3D a través de la web, el uso del estándar WebGL ha supuesto un gran avance, puesto que proporciona una proporciona una especificación sobre cómo renderizar datos 3D que los navegadores web deben implementar [Di Benedetto et al. 20 I4].

Otro campo esencial a tener en cuenta en las plataformas web enfocadas a la difusión del patrimonio, es la utilización de modelos semánticos, Open Semantic Web technologies, para hacer un uso más efectivo de los recursos y mayor velocidad de visualización, resolviendo problemas de interoperabilidad entre modelos 3D y el software asociado [Apollonio et al. $20 \mathrm{ll}$ ]. La principal ontología utilizada para la gestión de la documentación del patrimonio cultural es CIDOC-CRM CIDOC Conceptual Reference Model, que es compatible con otros vocabularios como el tesauro de Arte y Arquitectura (AAT) elaborado por el Getty Institute, y se usa para proveer la infraestructura semántica, proporcionando una ontología para el intercambio de información del patrimonio cultural y la integración de fuentes heterogéneas. Específicamente destinado a cubrir la información contextual, como los antecedentes históricos, geográficos y teóricos, se compone de términos para ser usados en la descripción, acceso e intercambio de información de objetos relacionados con el arte y la arquitectura. Se plantea una nueva aproximación a la catalogación del patrimonio arquitectónico gracias a la evolución de las tecnologías y los sistemas de representación, que permiten el almacenamiento de la información y su accesibilidad a través de una plataforma web de un modo sencillo e intuitivo, que responde a la mayoría de las necesidades ya mencionados de actualización permanente, flexibilidad, distribución selectiva, capacidad de introducir cualquier soporte, abaratamiento de costes e interacción con el usuario [Myers 20 I 6]. Los nuevos desarrollos se centran en implementar sistemas de información a través de plataformas web, capaces de gestionar y almacenar información en tiempo real, entre distintas bases de datos, favoreciendo la interacción a los usuarios no expertos y la visualización del modelo (fig. I).

Desde hace décadas, se ha podido comprobar como el uso de los Sistemas de Información Geográfica (SIG), son una herramienta adecuada para el almacenaje de información y su posterior análisis. Esta tecnología soluciona muchos de los problemas de visualización y anotación sobre los modelos geométricos, no solo sobre modelos de terrenos o excavaciones arqueológicas, sino también sobre objetos y en especial sobre edificios [Soler et al. 2017]. Permite administrar y almacenar grandes cantidades de información de distintos formatos: información alfanumérica de datos técnicos y científicos, formatos ráster y vectorial de planos, mapas, imágenes, dibujos, etc. Se caracterizan por servirse de una estructura semántica que facilita gestionar la información almacenada en una base de datos, razón por la cual, aporta las funcionalidades necesarias para la documentación completa del patrimonio y su uso para la realización de inventarios detallados y útiles para todo tipo de usuarios.

\section{Caso de estudio: Patrimonio Arquitectónico Mudéjar en Aragón}

El área de estudio es la Comunidad Autónoma de Aragón, donde se concentra un numeroso listado de bienes, ejemplo del patrimonio mudéjar, exclusivo de la península ibérica, cuya época comprende del siglo XII hasta el siglo XVII. Mientras en el Occidente cristiano predomina el gótico, en Aragón se desarrolla el arte mudéjar, reflejo de la pervivencia de la cultura musulmana en la península y con unas particularidades propias en el territorio aragonés.

Son especialmente significativas de este periodo, las tipologías de iglesia de nave única, con ábside poligonal de cinco o siete lados y con bóvedas de crucería sencilla, así como las iglesias-fortaleza. Destaca también la estructura de las torres, asimilables a los alminares de las mezquitas musulmanas, con dos torres, una envolviendo a la otra y entre medio las escaleras, y sobre este cuerpo se sitúa el campanario, normalmente poligonal. Los materiales tradicionales empleados en la construcción de esta tipología son el ladrillo, yeso, estuco, cerámica y madera. Destacando la cerámica y el yeso para realizar una ornamentación singular, con la utilización de formas geométricas y temas vegetales. 

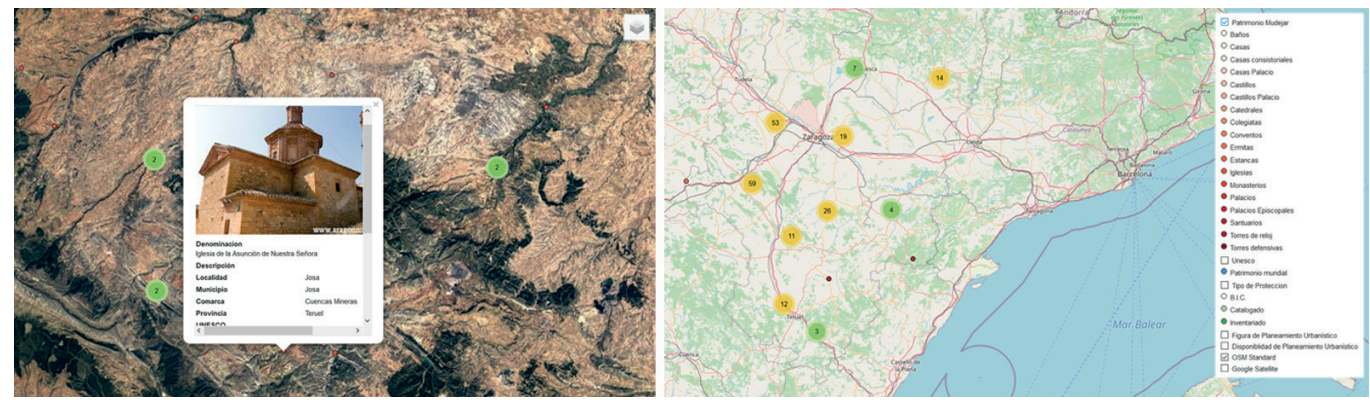

Gracias a la mezcla de estilos tan característica, la arquitectura mudéjar de Teruel fue declarada Patrimonio de la humanidad por la UNESCO el 28 de diciembre de 1986. Posteriormente, el I 4 de diciembre de 200 I se amplió la protección a toda la arquitectura mudéjar de Aragón. En este estudio se presenta el desarrollo de un Web-GIS para representar el patrimonio mudéjar en Aragón, un listado de 227 edificios que necesitan ser inventariados para su correcta documentación (fig. 2). Algunos de los bienes son especialmente representativos con elementos arquitectónicos singulares y forman parte del Patrimonio mundial. Esta situación precisa un Sistema de Información del Patrimonio Arquitectónico, una base de datos que pueda incorporar información relativa a la identificación y localización, datos históricos, tipo de protección, características geométricas, constructivas, estado de conservación y tipos de intervención; un soporte común que permita contener todos los materiales disponibles de un elemento patrimonial.

\section{Plataforma Web-GIS}

El diseño y desarrollo de este Web-GIS, se ha enfocado en la protección del patrimonio mudéjar de Aragón y su relación con el entorno y la normativa urbanística y de protección. La información gráfica de esta información y su relación con el patrimonio y su geolocalización, facilitan un soporte para el análisis espacial, para su conservación y divulgación. En esta primera fase de trabajo del desarrollo delWeb-GIS, se ha trabajado con información espacial en dos dimensiones y tablas temáticas de atributos que aportan la información complementaria necesaria, sobre un sistema de información geográfica. En una segunda fase del trabajo se incorporará información 3D en el propio sistema de información, y sobre el modelo de nube de puntos se incorporarán capas temáticas de información [Dell'Unto et al. 2016].

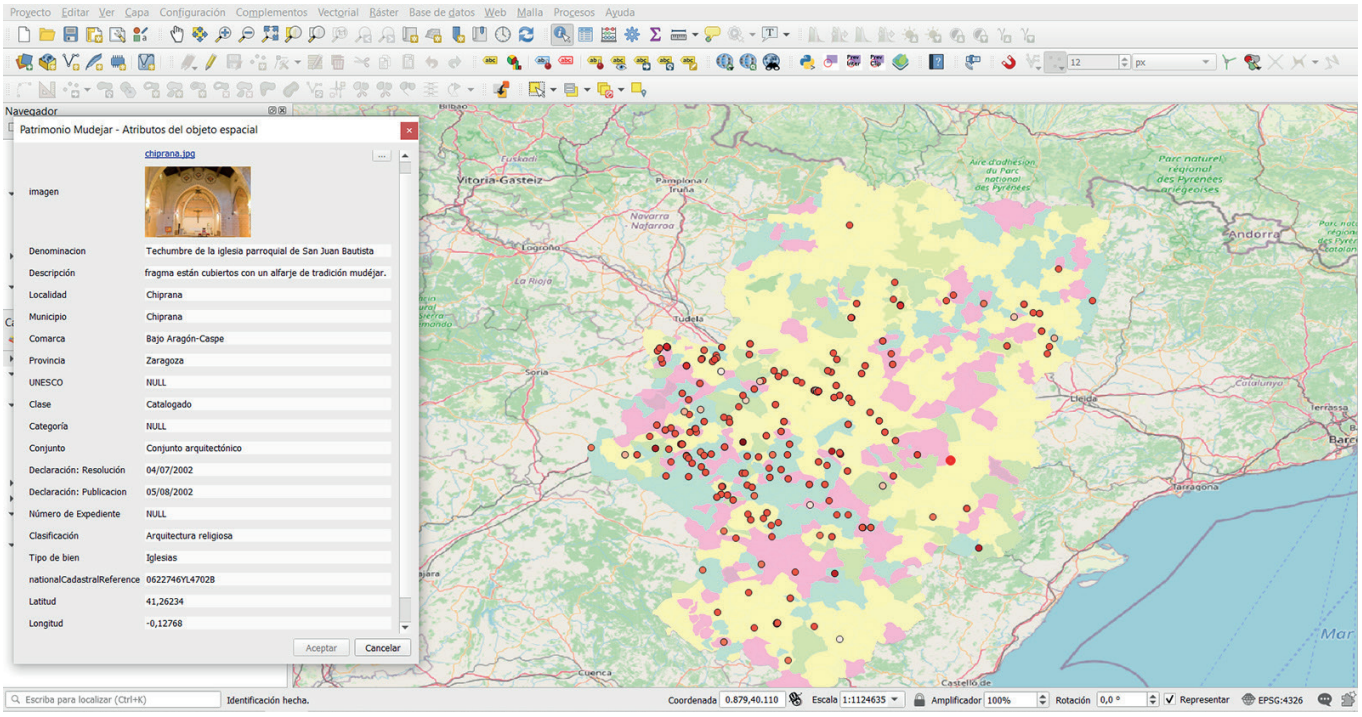


Fig. 3. Ejemplo de los distintos niveles de detalle para la representación de patrimonio.

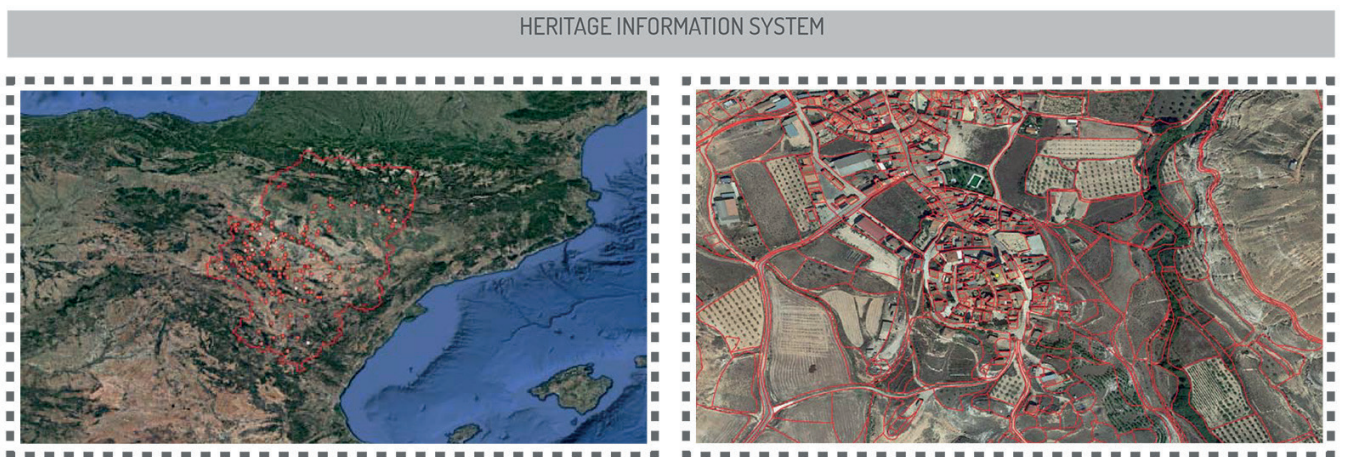

LOD Q_TERRITORY

LOD1_URBAN

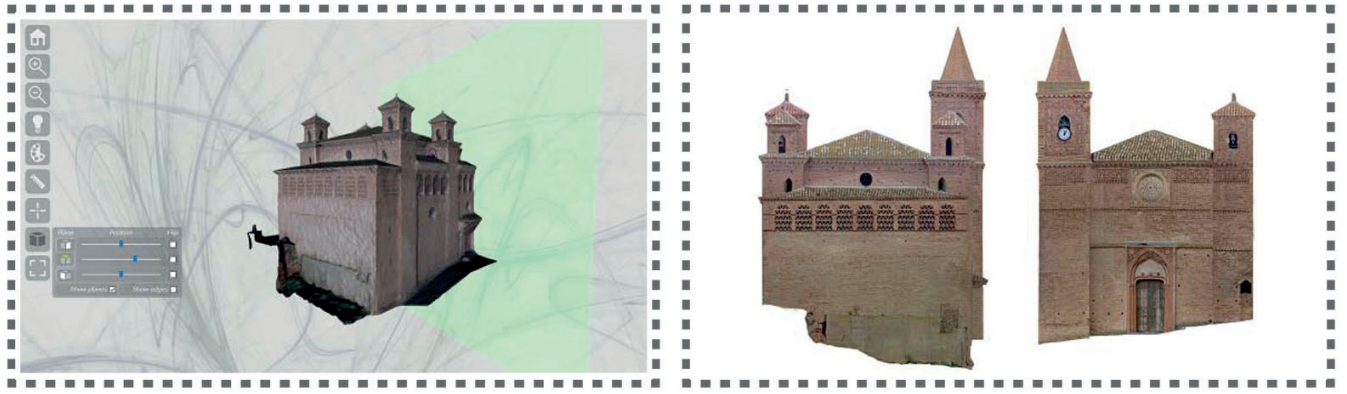

LOD 2_BUILDING

LOD 3_DETAIL

Para la representación de los objetos espaciales, se ha trabajado con diferentes niveles de detalle (LoD), que proporcionan un acceso fluido y eficiente a los datos, reduciendo el tiempo de latencia y la compresión [Scopigno et al. 2017]. La información se ha estructurado en distintos niveles de detalle, desde lo más genérico hasta el detalle: el nivel LoD 0 corresponde a la escala de territorio, en este caso reducido al ámbito de Aragón; LoD I muestra la escala urbana a nivel de ciudad, LoD 2 representa el modelo del edificio en 3D y para finalizar el LoD 3 alcanza el mayor nivel de detalle de los elementos constructivos del modelo del edificio (fig. 3). El desarrollo del web-GIS comenzó con la obtención de documentación para alcanzar el LoD 0. La escala del territorio está representada mediante información gráfica provista mediante un servicio WMS del IGN (Instituto Geográfico Nacional) y corresponde con información cartográfica, ortofotos o Lidar entre otros, que se incorporó a QGIS. El siguiente pasó se centró en obtener la información para conseguir un nivel de detalle a escala urbana, LoD I. El proceso consistió en obtener la base catastral de España en formato INSPIRE, que contiene la representación e información de las parcelas y manzanas urbanas de todo el territorio. A su vez, para complementar la información urbana, se incorporó una capa temática que contiene información respecto a las figuras de planeamiento urbanístico, las clases de suelo y la normativa urbanística (fig. 4).
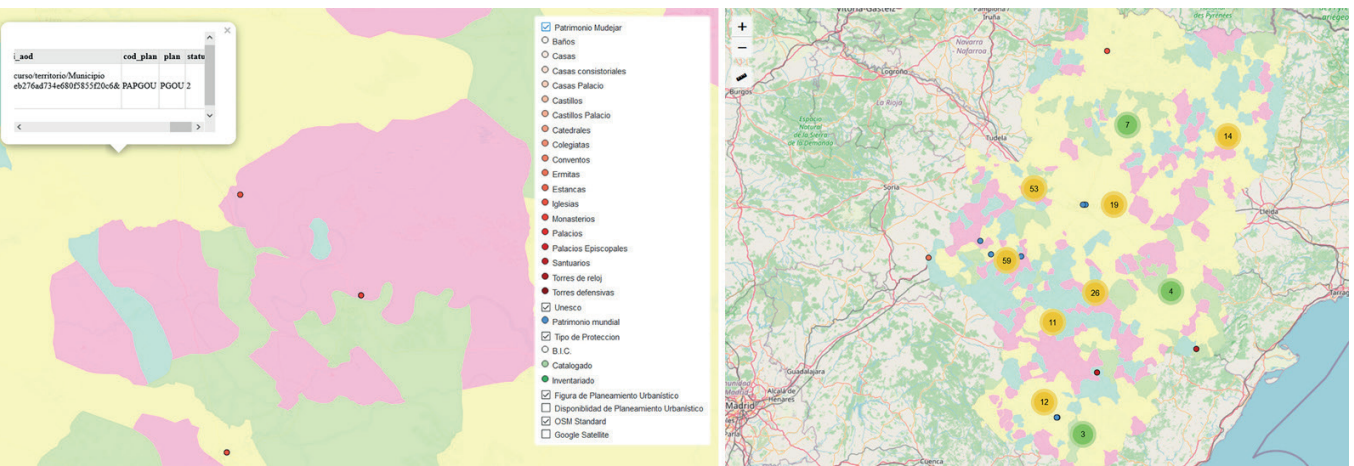
En esta fase, la labor más importante y complicada ha sido la de generar el listado del patrimonio mudéjar en Aragón. El Sistema de Información del Patrimonio Cultural Aragonés permite acceder al catálogo de Patrimonio arquitectónico aragonés, pero la búsqueda por criterios de estilo 'mudéjar' no muestra todos los resultados y la mayoría de ellos no están localizados geográficamente. El listado se ha completado tras buscar en varias bases de datos y localización manual de todos los edificios a través de Google Maps para obtener sus coordenadas. Actualmente no existe una entidad oficial que haya creado un mapa que pueda descargarse con todo el listado completo de edificios y su ficha de inventario.

En la elección del software se ha tenido en consideración lo expuesto anteriormente respecto a las necesidades de interoperabilidad y estandarización, eligiendo herramientas de software libre como QGIS, que ha sido empleado para la visualización e introducción de los datos espaciales. Como principal base de datos se ha utilizado PostgreSQL, a través de su extensión Post GIS. Esta, permite la creación de tablas de atributos con información geométrica y espacial que se almacenan en una Geo-DB. Una vez incorporada la información, mediante una plantilla se puede acceder a la visualización y consulta.

Toda la información correspondiente al inventario del patrimonio se ha diseñado para cumplir con el marco metodológico del proyecto. La Geo-DB concentra en una tabla de atributos todos los registros relevantes de las entidades del proyecto, relacionando los datos de forma jerárquica y con una estructura semántica basada en los estándares del CIDOC (fig. 5). Al incorporar la base catastral y asociar la tabla de información que contiene los atributos de todos los edificios, así como su geolocalización, permite conectar ambas tablas mediante la referencia catastral y posteriormente asociar el objeto espacial a la capa de planeamiento urbanístico, completando la información que relaciona el edificio con su entorno (fig. 6).

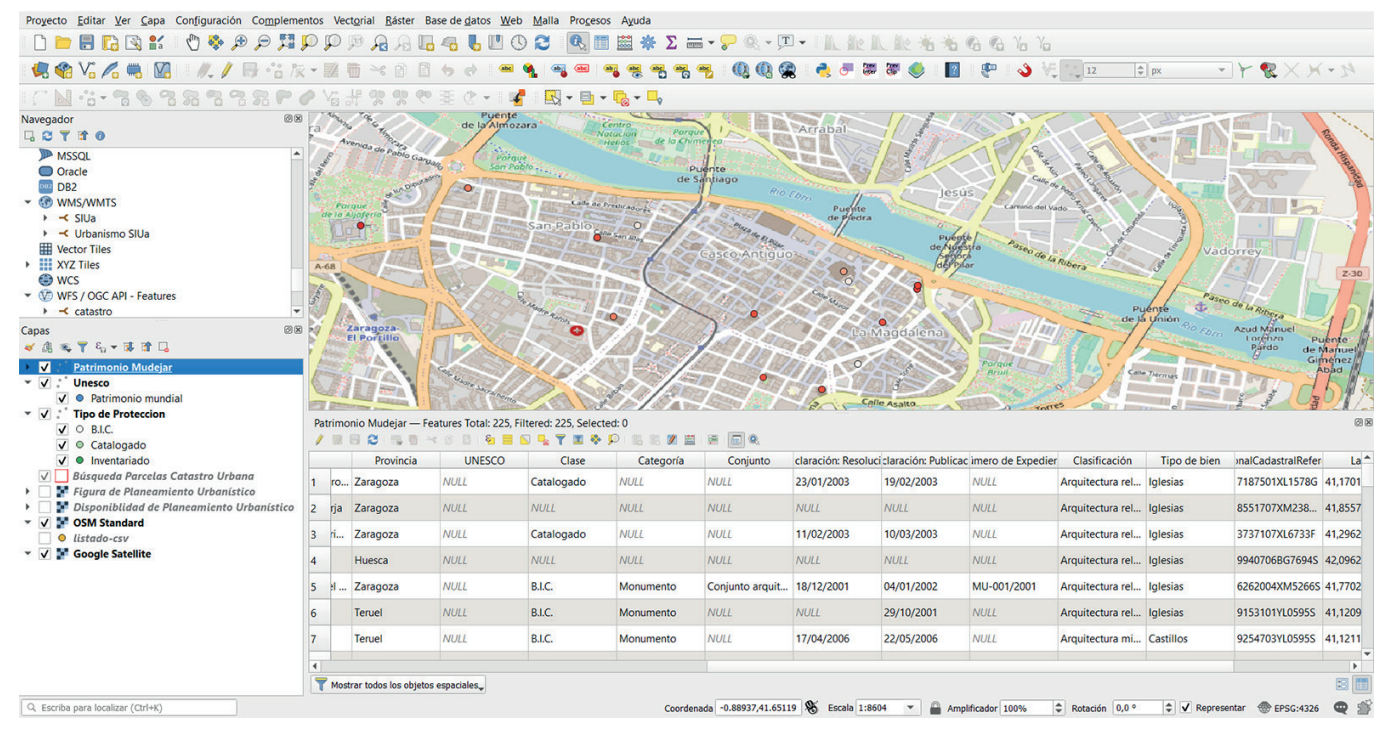

\section{Conclusiones}

La representación del patrimonio mediante su localización espacial, conjuntamente con la información de planeamiento urbanístico y el territorio, proporciona una herramienta potente para la administración. Supone un instrumento adicional para la toma de decisiones, facilitando la elaboración de inventarios encaminados a la protección y conservación, y contribuye a dotar de una visión del edificio a escala urbana y territorial, no solo como un ente aislado. Pero a su vez, tiene un carácter divulgativo que puede ser utilizado para poner en valor el patrimonio arquitectónico mudéjar en Aragón con fines turísticos. Desde un punto de vista gráfico, la representación de la información en varios niveles de detalle, distintos tipos de datos y soportes, aporta una visión completa del edificio con múltiples lecturas. 
Fig. 6. Representación conjunta de distintas capas de temáticas que aportan información variada del edificio para la toma de decisiones.

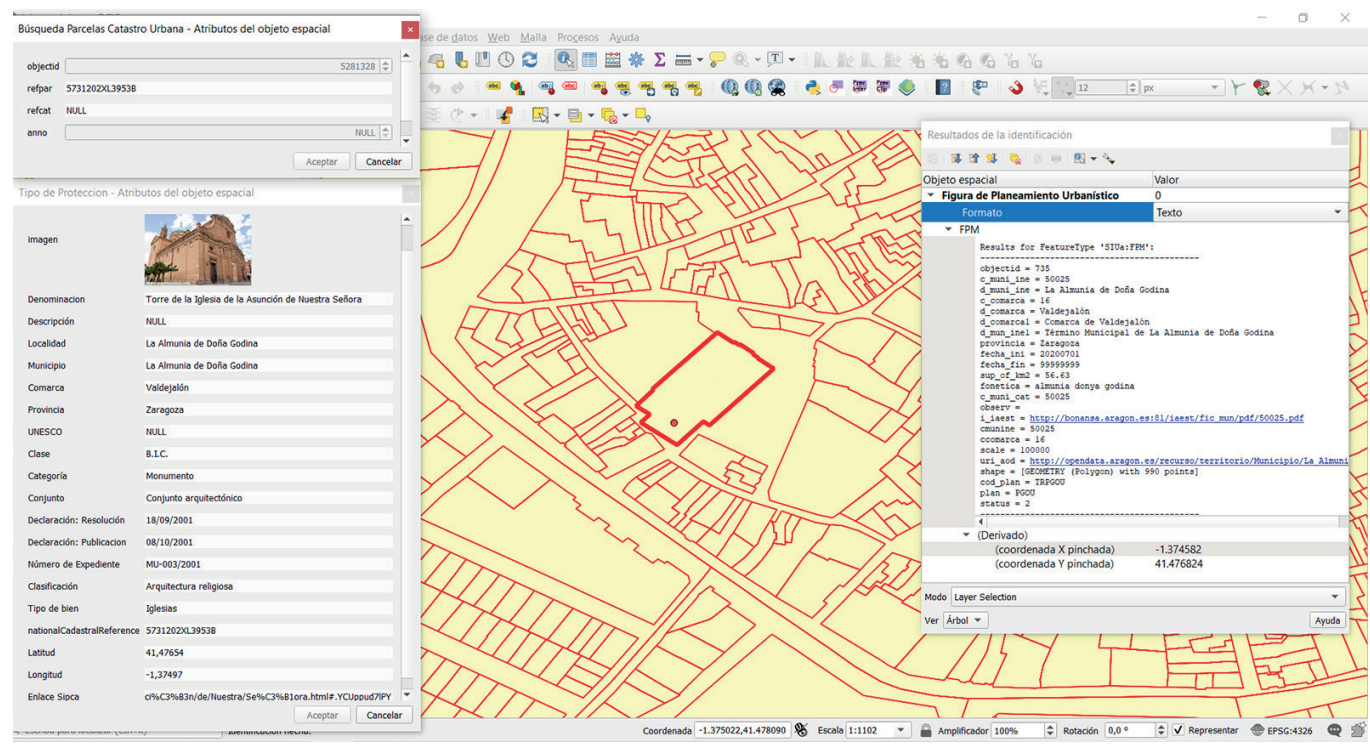

\section{Referencias}

Apollonio F. I. et al. (20I I). Construction, Management andVisualization of 3D Models of Large Archeological and Architectura Sites for E-Heritage GIS Systems. En XXIIIrd International CIPA Symposium. Prague, Czech Republic, I2-16, September 201 I.

Cerutti E., Noardo F., Spanò A. (20I5). Architectural heritage semantic data managing and sharing in GIS. En GISTAM 2015 - Ist International Conference on Geographical Information Systems Theory, Applications and Management, Proceedings. Barcelona, 28-30 April 2015, pp. 121-128. Barcelona: SciTePress.

Dell'Unto N. et al. (2016). Experiencing Ancient Buildings from a 3D GIS Perspective: A Case Drawn from the Swedish Pompeii Project. En Journal of Archaeological Method and Theory, vol. 23, n. I, pp. 73-94.

Denard H. (2009). The London Charter for the Computer-Based Visualization of Cultural Heritage. London, UK: King's College London.

Di Benedetto M. et al. (20I4).Web and Mobile Visualization for Cultural Heritage. En M. loannides, E. Quak (Eds.). 3D Research Challenges in Cultural Heritage. Lecture Notes in Computer Science, vol. 8355, pp. I 8-35. Berlin: Springer

Myers D., Dalgity A. (2016). The Arches heritage inventory and management system: a platform for the heritage field. En Journal of Cultural Heritage Management and Sustainable Development, vol. 6, n. 2, pp. 21 3-224.

Principios de Sevilla (20I I). International Principles of Virtual Archaeology. Sevilla: INNOVA/SEAV.

Scopigno R. et al. (2017). Delivering and using 3D models on the web: are we ready?. En Virtual Archaeology Review, vol. 8, n. 17, pp. I-9.

Sistema de Información del Patrimonio Cultural Aragonés <http://www.sipca.es/> (consultado el I5 de febrero de 202I).

Soler F., Melero F.J., Luzón M.V. (2017). A complete 3D information system for cultural heritage documentation. En Journal of Cultural Heritage, vol. 23, pp. 49-57.

Statham N. (2019). Scientific Rigour of Online Platforms for 3DVisualization of Heritage. En Virtual Archaeology Review, vol. I0, n. 20, pp. $1-16$

UNESCO (1972). Convención sobre la protección del patrimonio mundial, cultural y natural. World Heritage Comitee.

\section{Autor}

Marta Quintilla, Universidad de Zaragoza, mquintilla@unizar.es

Para citar este artículo: Quintilla Marta (202I). Desarrollo de un Web-GIS para el patrimonio arquitectónico Mudéjar/Development of a WebGIS for the Mudejar Architectural Heritage. In Arena A. Arena M. Mediati D. Raffa P. (a cura di) Connettere. Un disegno per annodare e tessere Linguagri Distanze Tecnologie. Atti del $42^{\circ}$ Convegno Internazionale dei Docenti delle Discipline della Rappresentazione/Connecting Drawing for weaving relationship. Languages Distances Technologies. Proceedings of the 42th International Conference of Representation Disciplines Teachers. Milano: FrancoAngeli, pp. 2607-2620 


\title{
Development of a Web-GIS for the Mudejar Architectural Heritage
}

\author{
Marta Quintilla
}

\section{Abstract}

This study presents the development of a Web-GIS to represent the Mudejar heritage in Aragon, a list of 227 buildings that need to be inventoried for their correct documentation. Some of the buildings are particularly representative with unique architectural elements and are part of the World Heritage. This situation requires an Information System of the Architectural Heritage, a database that can incorporate information related to the identification, location, historical data, type of protection, geometric and constructive characteristics, state of conservation and types of intervention; a common support that allows to contain all the available materials of a patrimonial element. The design and development of this Web-GIS has focused on the protection of the Mudejar heritage of Aragon and its relationship with the environment and the urban and protection regulations. The graphic information of this information and its relationship with heritage and its geolocation, provide a support for spatial analysis, for its conservation and dissemination. It is an additional instrument for decision-making, facilitating the preparation of inventories aimed at protection and conservation, and contributes to providing a vision of the building on an urban and territorial scale, not only as an isolated entity.

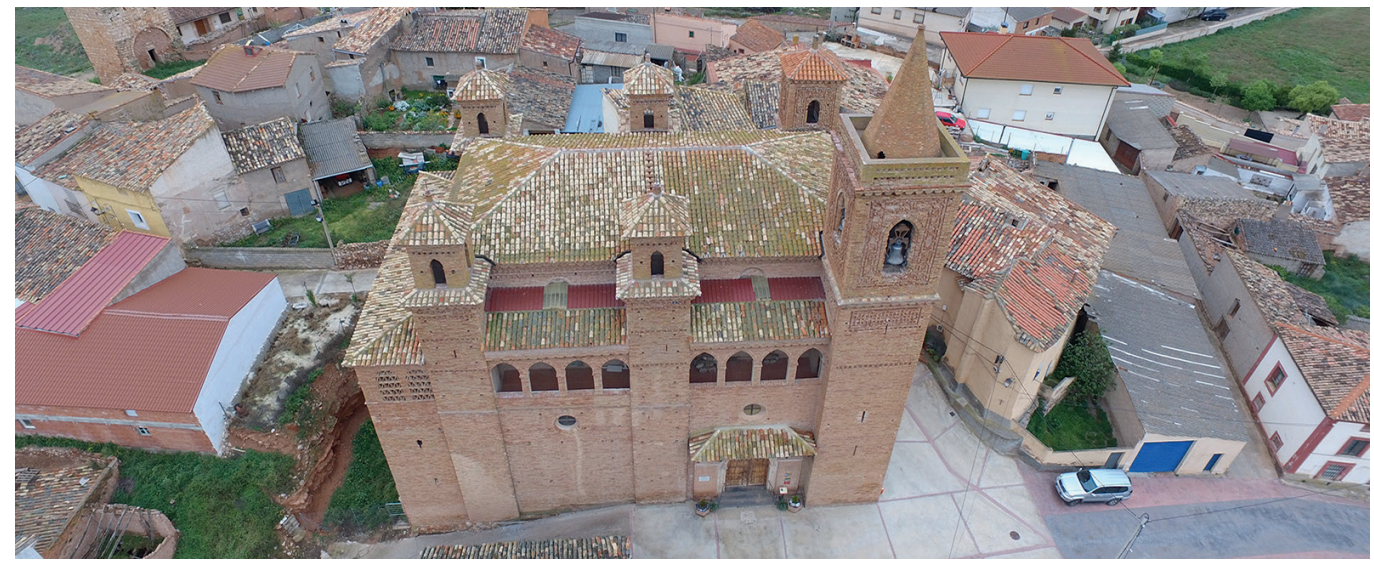




\section{Introduction}

The dissemination of Cultural Heritage in recent decades has been linked to the development of computer tools used by researchers for the visualization and management of information. In turn, it has affected the way researchers work, since it allows the generation of more documentation with great precision and must be stored and managed in a fast, accessible and simple way.

Since the 1972 UNESCO Convention [UNESCO 1972], in which the needs of conservation and protection of the Heritage were promoted, as well as "adopting the appropriate legal, scientific, technical, administrative and financial measures to identify, protect, conserve, revalue and rehabilitate that heritage", all disciplines have worked jointly to carry out this work.

Advances in the working methodology and in the way of documentation in the field of the digital visualization of Heritage have been governed mainly by the London Charter [Denard 2009], on heritage visualization and the Seville Principles [International Forum of Virtual Archaeology $20 \mathrm{ll}$ l], focused on virtual archeology. In them, transparency in the representation is urged, clearly differentiating the original from the reconstructed, in addition to recommending the adaptation of the visualization to the objectives of research, preservation and dissemination [Statham 2019].

Currently, the preparation of documentation for the conservation, dissemination and protection of heritage, represents a great challenge for professionals. The heterogeneity of data, laws, standards, technologies and audiences, makes it difficult to properly organize information. The choice of the Management System by the institutions causes problems of transfer, communication and difficulty of knowledge distribution among the different actors that work around heritage, as well as with other inventories. In general, the problems are common in most countries: low degree of technological use, little updating and standardization. Therefore, ensuring correct information over time is a priority.

The trend for the maintenance and interoperability between databases is to establish a common international regulatory framework, through the use of standards. At the European Union level, work is being done on numerous projects for the guardianship and protection of cultural property such as Parthenos, Ariadne, Carare or 3D-Icons, among others, dictating common minimums for the conservation and documentation of heritage in all the countries of the Union. Initiatives are being promoted to homogenize and unify through the standardization of information, through the development of guides that include international recommendations and standards for the inventory and documentation of heritage, as well as standards for the exchange of documentation, metadata and geographic information.

\section{Interoperability and standard issues}

To allow maximum interoperability and accessibility, the use of open source software and language guarantees the correct exchange of information and ensures its permanence and maintenance over time despite continuous technological advances, favoring institutions to maintain their wealth management systems.

The development of standards for information exchange is being carried out by the W3C (World Wide Web Consortium), through the creation of standards such as XML (eXtensible Markup Language) that provide tools for the exchange of information and metadata between applications. The XML language is also used for the semantic structure of information, but it does not consider the spatial dimension of them. To this end, the OGC (Open Geospatial Consortium) has put its efforts into defining standards that allow the interoperability of this type of data through the web, developing, among others, the GML (Geographic Markup Language) standard, very similar to XML, but focused on showing geographic objects [Cerutti et al. 20 I5]. This language is used by international directives such as INSPIRE (Infrastructure for Spatial Information in Europe) to promote the development of spatial 
data infrastructures and the standardized exchange of information. In the case of 3D data visualization via the web, the use of the WebGL standard has been a breakthrough, since it provides a specification on how to render 3D data that web browsers must implement [Di Benedetto et al. 2014].

Another essential field to take into account in web platforms focused on the dissemination of heritage, is the use of semantic models, Open Semantic Web technologies, to make a more effective use of resources and greater visualization speed, solving interoperability problems between 3D models and associated software [Apollonio et al. 20I I]. The main ontology used for the management of cultural heritage documentation is CIDOC-CRM CIDOC Conceptual Reference Model, which is compatible with other vocabularies such as the Art and Architecture Thesaurus (AAT) prepared by the Getty Institute, and is used to provide the semantic infrastructure, providing an ontology for the exchange of cultural heritage information and the integration of heterogeneous sources. Specifically intended to cover contextual information, such as historical, geographical and theoretical backgrounds, it is composed of terms to be used in the description, access and information exchange of objects related to art and architecture.

A new approach to the cataloging of architectural heritage is proposed thanks to the evolution of technologies and representation systems, which allow the storage of information and its accessibility through a web platform in a simple and intuitive way, which responds to most of the aforementioned needs for permanent updating, flexibility, selective distribution, the ability to introduce any support, lower costs and user interaction [Myers 2016]. The new developments focus on implementing information systems through web platforms, capable of managing and storing information in real time, between different databases, favoring the interaction of non-expert users and the visualization of the model (fig. I).

For decades, it has been possible to verify how the use of Geographic Information Systems (GIS) are an adequate tool for storing information and its subsequent analysis. This technology solves many of the visualization and annotation problems on geometric models, not only on terrain models or archaeological excavations, but also on objects and especially on buildings [Soler et al. 20 17]. It allows managing and storing large amounts of information in different formats: alphanumeric information of technical and scientific data, raster and vector formats of plans, maps, images, drawings, etc. They are characterized by using a semantic structure that facilitates managing the information stored in a database, which is why it provides the necessary functionalities for the complete documentation of the heritage and its use to carry out detailed and useful inventories for all types of users.

\section{Case study: Mudejar architectural heritage in Aragon}

The study area is the Autonomous Community of Aragon, where a large list of assets is concentrated, an example of the Mudejar heritage, exclusive to the Iberian Peninsula, whose period ranges from the $12^{\text {th }}$ to the $17^{\text {th }}$ century. While in the Christian West the Gothic predominates, in Aragon Mudejar art develops, a reflection of the survival of Muslim culture in the peninsula and with its own particularities in the Aragonese territory.

Especially significant from this period are the types of church with a single nave, with a polygonal apse of five or seven sides and with simple ribbed vaults, as well as fortress churches. Also noteworthy is the structure of the towers, similar to the minarets of Muslim mosques, with two towers, one wrapping the other and between the stairs, and on this body is the bell tower, usually polygonal. The traditional materials used in the construction of this typology are brick, plaster, stucco, ceramic and wood. Highlighting ceramics and plaster to make a unique ornamentation, with the use of geometric shapes and plant themes.

Thanks to the mixture of styles so characteristic, the Mudejar architecture of Teruel was declared a World Heritage Site by UNESCO on December 28, 1986. Later, on December I4, 200 I, the protection was extended to all the Mudejar architecture of Aragon. 
Fig. I. General view of the Web-GIS of the Mudejar Heritage in Aragon.
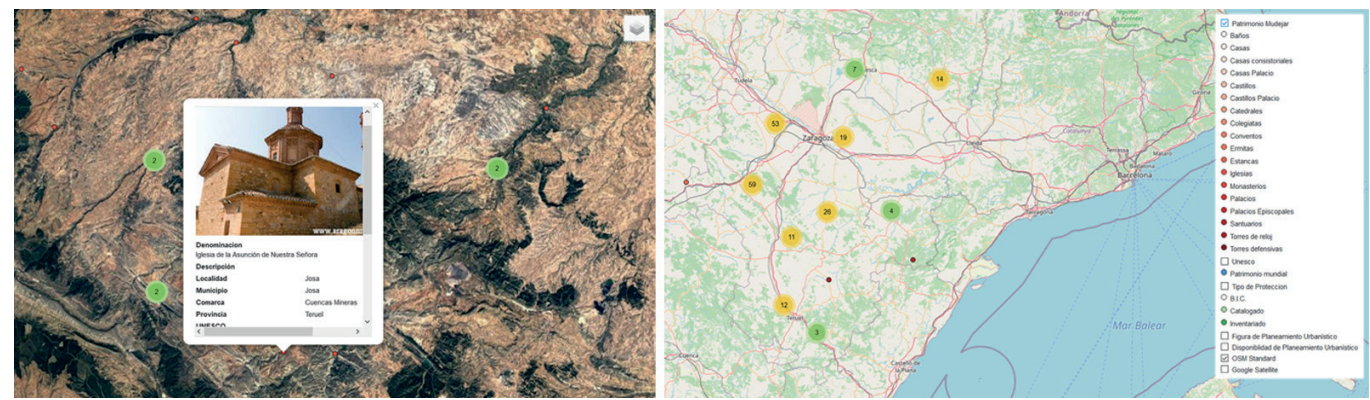

This study presents the development of a Web-GIS to represent the Mudejar heritage in Aragon, a list of 227 buildings that need to be inventoried for their correct documentation (fig. 2). Some of the buildings are especially representative with unique architectural elements and are part of the World Heritage. This situation requires an Information System of the Architectural Heritage, a database that can incorporate information related to the identification and location, historical data, type of protection, geometric and constructive characteristics, state of conservation and types of intervention; a common support that allows to contain all the available materials of a patrimonial element.

\section{Web-GIS platform}

The design and development of this Web-GIS has focused on the protection of the Mudejar heritage of Aragon and its relationship with the environment and urban and protection regulations. The graphic information of this information and its relationship with heritage and its geolocation, provide a support for spatial analysis, for its conservation and dissemination. In this first phase of the Web-GIS development work, we have worked with spatial information in two dimensions and thematic tables of attributes that provide the necessary complementary information about a geographic information system. In a second phase of the work, 3D information will be incorporated into the information system itself, and thematic layers of information will be incorporated on the point cloud model [Dell'Unto et al. 20।6].

For the representation of spatial objects, we have worked with different levels of detail (LoD), which provide fluid and efficient access to data, reducing latency and compression

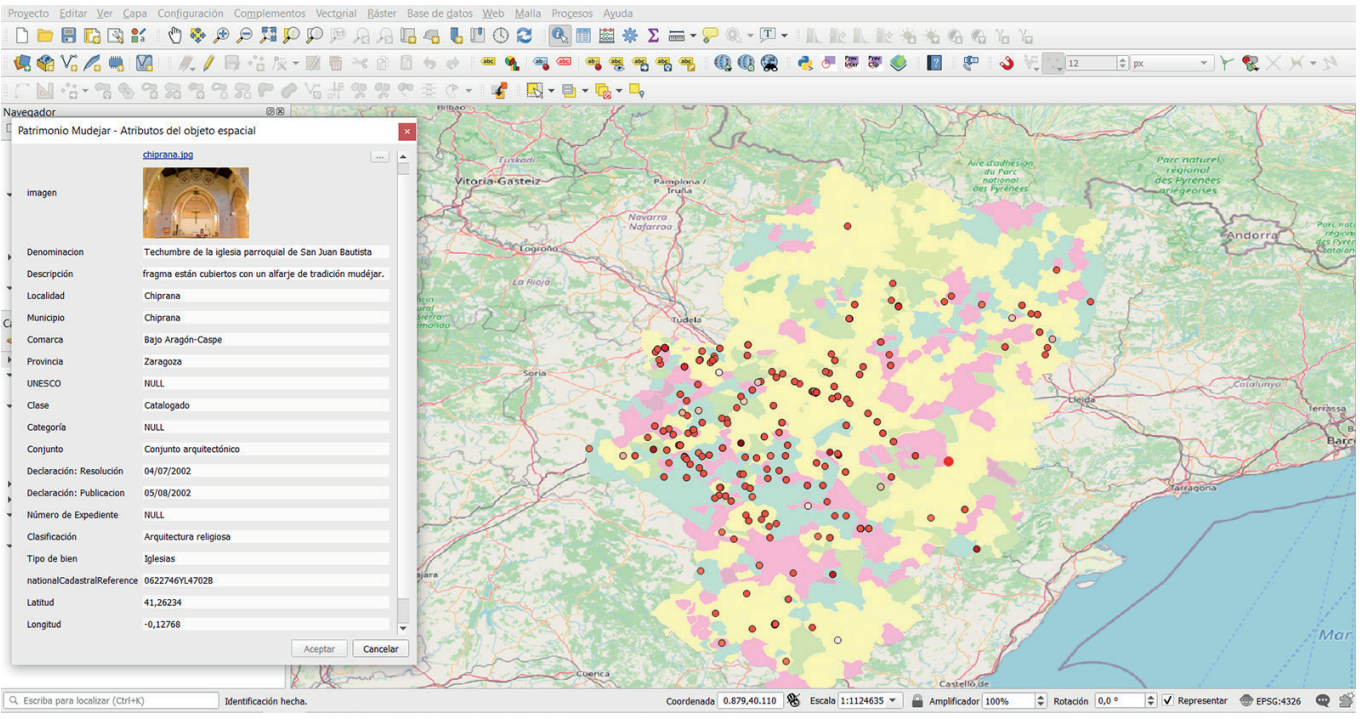


Fig. 3. Example of the different levels of detail for the heritage representation.

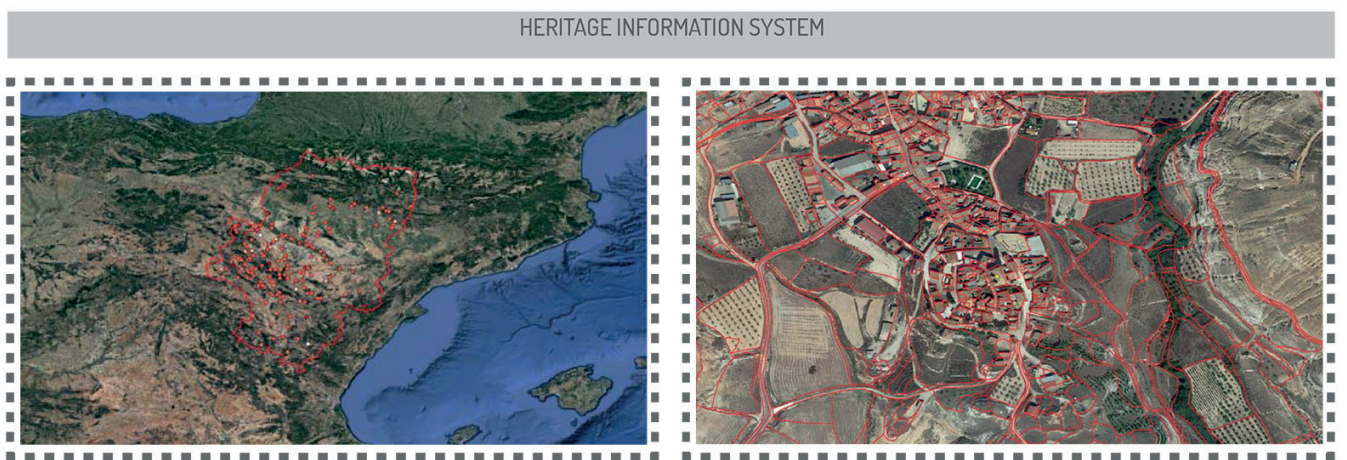

LOD O_TERRITORY

LOD1_URBAN

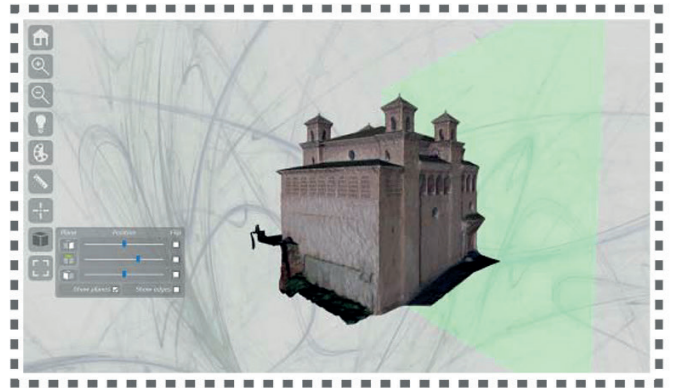

LOD 2_BUILDING

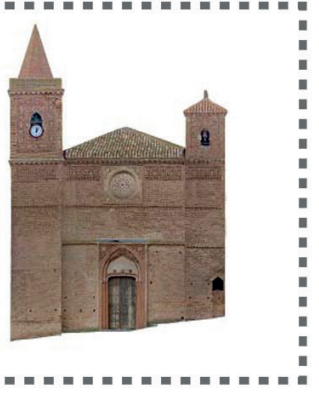

LOD 3_DETAIL

[Scopigno et al. 20 I 7]. The information has been structured in different levels of detail, from the most generic to the detailed: the LoD level 0 corresponds to the scale of territory, in this case reduced to the scope of Aragon; LoD I shows the urban scale at the city level, LoD 2 represents the building model in 3D and finally, LoD 3 reaches the highest level of detail of the construction elements of the building model (fig. 3).

The development of the web-GIS began with obtaining documentation to achieve LoD 0. The scale of the territory is represented by graphic information provided through a WMS service of the IGN (National Geographic Institute) and corresponds to cartographic information, orthophotos or Lidar among others, which was incorporated into QGIS. The next step focused on obtaining the information to achieve a level of detail on an urban scale, LoD I. The process consisted of obtaining the cadastral base of Spain in INSPIRE format, which contains the representation and information of the urban parcels and blocks of all the territory. In turn, to complement the urban information, a thematic layer was incorporated that contains information regarding urban planning figures, land classes and urban regulations (fig. 4).
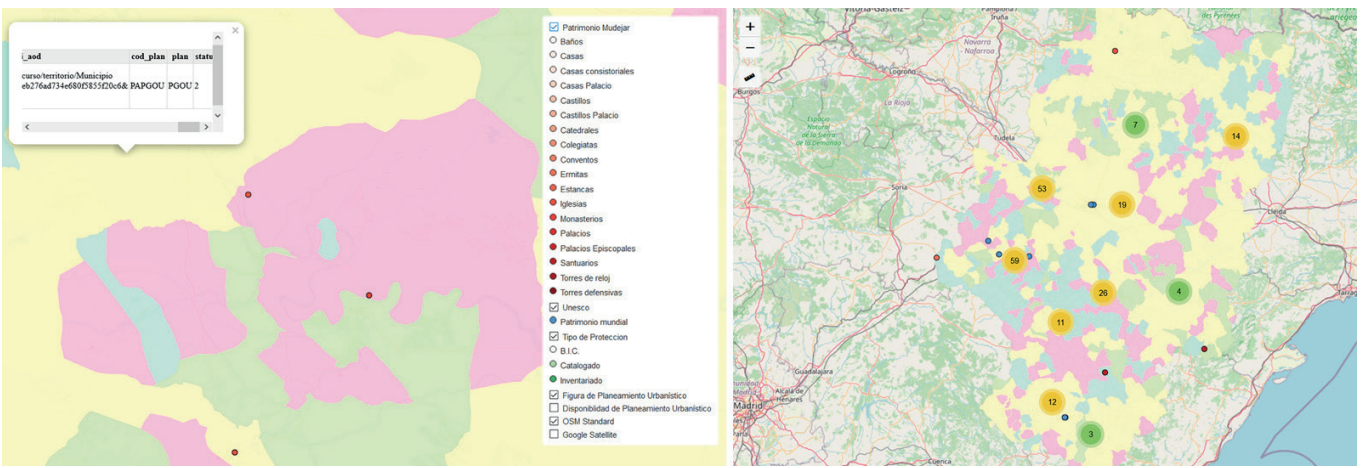
In this phase, the most important and complicated task has been to generate the list of Mudejar heritage in Aragon. The Aragonese Cultural Heritage Information System allows access to the Aragonese architectural heritage catalog, but the search for 'Mudejar' style criteria does not show all the results and most of them are not geographically located. The list has been completed after searching in various databases and manually locating all the buildings through Google Maps to obtain their coordinates. Currently there is no official entity that has created a map that can be downloaded with the complete list of buildings and their inventory file.

In the choice of software, the above has been taken into consideration regarding the needs of interoperability and standardization, choosing free software tools such as QGIS, which has been used for the visualization and introduction of spatial data. PostgreSQL has been used as the main database, through its Post GIS extension. This allows the creation of attribute tables with geometric and spatial information that are stored in a Geo-DB. Once the information has been incorporated, through a template you can access the visualization and consultation.

All the information corresponding to the heritage inventory has been designed to comply with the methodological framework of the project. The Geo-DB concentrates in an attribute table all the relevant records of the project entities, relating the data in a hierarchical way and with a semantic structure based on the CIDOC standards (fig. 5). By incorporating the cadastral base and associating the information table that contains the attributes of all the buildings, as well as their geolocation, it allows connecting both tables through the cadastral reference and later associating the spatial object with the urban planning layer, completing the information that relates the building to its surroundings (fig. 6).

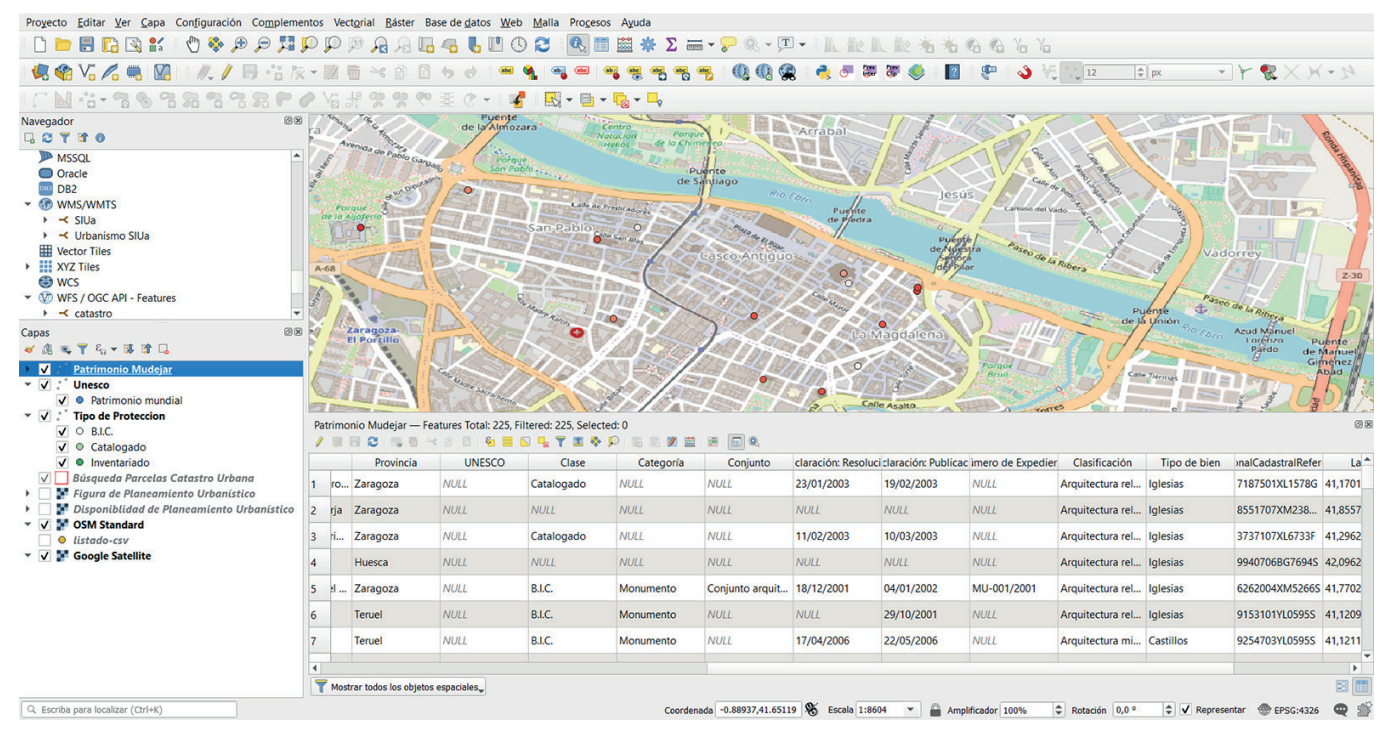

\section{Conclusions}

The representation of heritage through its spatial location, together with information on urban planning and territory, provides a powerful tool for administration. It is an additional instrument for decision-making, facilitating the preparation of inventories aimed at protection and conservation, and contributes to providing a vision of the building on an urban and territorial scale, not only as an isolated entity. But at the same time, it has an informative character that can be used to value the Mudejar architectural heritage in Aragon for tourist purposes. From a graphic point of view, the representation of information at various levels of detail, different types of data and supports, provides a complete vision of the building with multiple readings. 
Fig. 6. Joint representation of different layers of themes that provide varied information about the building for decisionmaking.

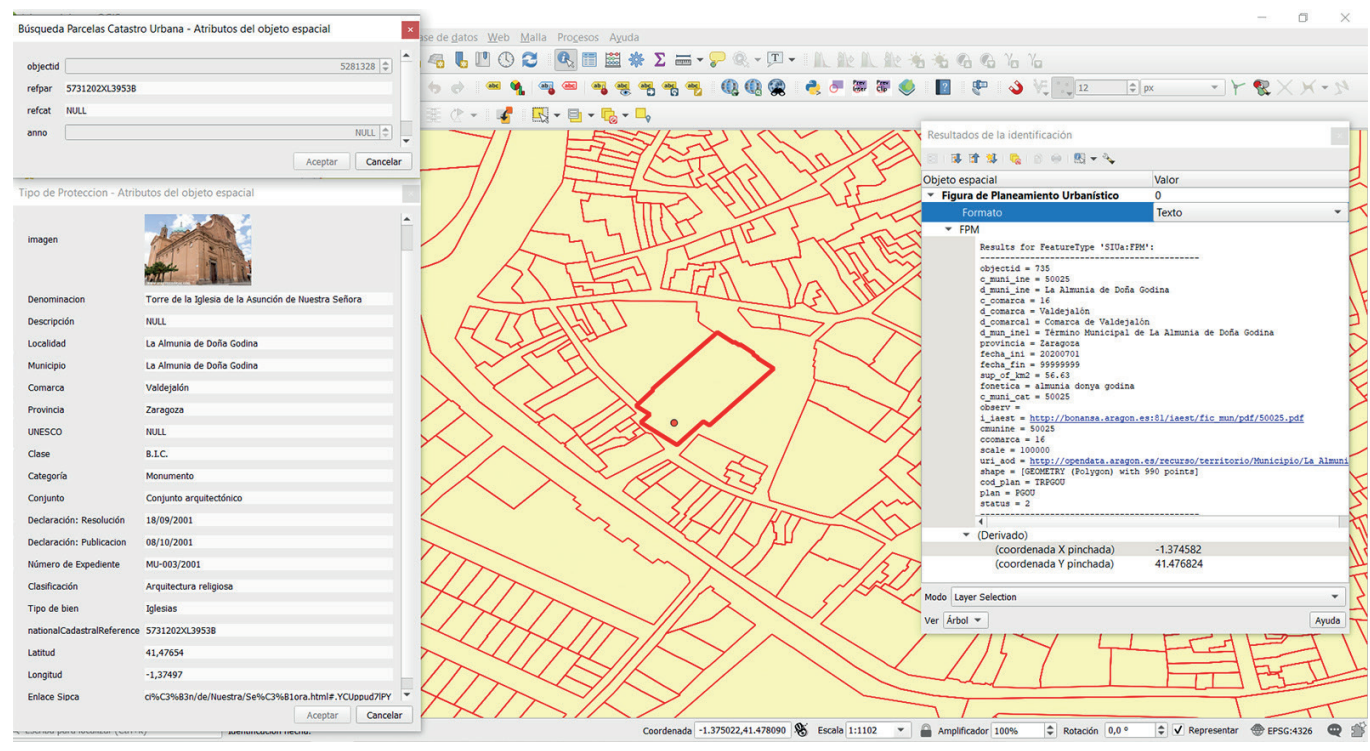

\section{References}

Apollonio F. I. et al. (20I I). Construction, Management andVisualization of 3D Models of Large Archeological and Architectura Sites for E-Heritage GIS Systems. In XXIIIrd International CIPA Symposium. Prague, Czech Republic, I2- I6, September 201 I.

Cerutti E., Noardo F., Spanò A. (20I5). Architectural heritage semantic data managing and sharing in GIS. In GISTAM 2015 - Ist International Conference on Geographical Information Systems Theory, Applications and Management, Proceedings. Barcelona, 28-30 April 2015, pp. 121-128. Barcelona: SciTePress.

Dell'Unto N. et al. (2016). Experiencing Ancient Buildings from a 3D GIS Perspective: A Case Drawn from the Swedish Pompeii Project. In Journal of Archaeological Method and Theory, vol. 23, n. I, pp. 73-94.

Denard H. (2009). The London Charter for the Computer-Based Visualization of Cultural Heritage. London, UK: King's College London.

Di Benedetto M. et al. (20I4).Web and Mobile Visualization for Cultural Heritage. In M. loannides, E. Quak (Eds.). 3D Research Challenges in Cultural Heritage. Lecture Notes in Computer Science, vol. 8355, pp. 18-35. Berlin: Springer.

Myers D., Dalgity A. (2016). The Arches heritage inventory and management system: a platform for the heritage field. In Journal of Cultural Heritage Management and Sustainable Development, vol. 6, n. 2, pp. $213-224$

Principios de Sevilla (20I I). International Principles of Virtual Archaeology. Sevilla: INNOVA/SEAV.

Scopigno R. et al. (2017). Delivering and using 3D models on the web: are we ready? In Virtual Archaeology Review, vol. 8, n. I7, p. $1-9$.

Sistema de Información del Patrimonio Cultural Aragonés <http://www.sipca.es/> (accessed 202I, February I5).

Soler F., Melero F.J., Luzón M.V. (2017). A complete 3D information system for cultural heritage documentation. In Journal of Cultural Heritage, vol. 23, pp. 49-57.

Statham N. (2019). Scientific Rigour of Online Platforms for 3D Visualization of Heritage. In Virtual Archaeology Review, vol. I0, n. 20, pp. $1-16$

UNESCO (1972). Convención sobre la protección del patrimonio mundial, cultural y natural. World Heritage Comitee.

Author

Marta Quintilla, Universidad de Zaragoza, mquintilla@unizar.es

To cite this chapter: Quintilla Marta (202I). Desarrollo de un Web-GIS para el patrimonio arquitectónico Mudéjar/Development of a Web-GIS for the Mudejar Architectural Heritage. In Arena A., Arena M., Mediati D., Raffa P. (a cura di). Connettere. Un disegno per annodare e tessere Linguaggi Distanze Tecnologie. Atti del $42^{\circ}$ Convegno Internazionale dei Docenti delle Discipline della Rappresentazione/Connecting. Drawing for weaving relationship. Languages Distances Technologies. Proceedings of the 42th International Conference of Representation Disciplines Teachers. Milano: FrancoAngeli, pp. 2607-2620. 